\title{
The pathophysiology of chronic graft-versus-host disease: the unveiling of an enigma
}

\author{
Chang-Ki Min \\ Division of Hematology, Department of Internal Medicine, The Catholic University of Korea, Seoul, Korea
}

p-ISSN 1738-7949 / e-ISSN 2092-9129

DOI: $10.5045 / \mathrm{kjh} .2011 .46 .2 .80$

Korean J Hematol 2011;46:80-7.

Received on June 9, 2011

Accepted on June 10, 2011

*This study was supported by the Korea Healthcare Technology R\&D Project, Ministry of Health, Welfare \& Family Affairs, Republic of Korea (grant no. A092258).

\section{Correspondence to \\ Chang-Ki Min, M.D. \\ Department of Internal Medicine, Seoul St. Mary's Hospital, The Catholic University of Korea, 505 Banpo-dong, Seocho-gu, Seoul 137-701, Korea \\ Tel: +82-2-2258-6053 \\ Fax: +82-2-599-3589 \\ E-mail: ckmin@catholic.ac.kr \\ (C) 2011 Korean Society of Hematology}

Chronic graft-versus-host disease (CGVHD) is one of the most significant complications of long-term survivors after allogeneic hematopoietic stem cell transplantation (allo-HSCT). CGVHD may have protean manifestations and can pose unique diagnostic and therapeutic challenges. New recommendations that emphasize the importance of qualitative differences, as opposed to time of onset after HSCT, are now being used to standardize the diagnosis and clinical assessment of CGVHD, but they require validation. During the past 3 decades, experimental studies and clinical observations have elucidated the mechanisms of acute GVHD, but its biology is much less well-understood. Experimental studies have generated at least 4 theories to explain the pathophysiology of CGVHD: (1) thymic damage and the defective negative selection of T cells, (2) regulatory T cell deficiencies, (3) auto-antibody production by aberrant B cells, and (4) the formation of profibrotic lesions. Mouse models have provided important insights into the pathophysiology of CGVHD, and these have helped improve clinical outcomes following allo-HSCT, but no animal model fully replicates all of the features of CGVHD in humans. In this article, recent clinical changes, the pathogenesis of CGHVD, the cellular and cytokine networks implicated in its pathogenesis, and the animal models used to devise strategies to prevent and treat CGVHD are reviewed.

Key Words Chronic graft-versus-host disease, Pathophysiology, Acute graft-versushost disease, Fibrosis, Mouse model

\section{INTRODUCTION}

Chronic graft-versus-host disease (CGVHD) remains a major cause of late morbidity and mortality after allogeneic hematopoietic stem cell transplantation (allo-HSCT) [1]. The incidence of CGVHD following allo-HSCT ranges from 25\% to $80 \%$; the occurrence of CGVHD is associated with immune dysfunction and thus, a risk of infection and reduced quality of life [2], even though CGVHD is also associated with a lower relapse rate, presumably because of graft-versus-leukemia effects [3]. Over the past 10 years, CGVHD has emerged as the most troublesome complication of allo-HSCT. Improvements in human histocompatibility antigen (HLA) typing for unrelated transplantation, the adoption of new acute GVHD prophylaxis measures, reductions in conditioning regimen intensity, the introduction of new antimicrobial agents, and advances in supportive care have all helped to mitigate early morbidity and mortality in patients after allo-HSCT. However, because more and more patients survive the early post-transplant period, the number of individuals at risk for CGVHD continues to grow. This trend, in conjunction with the escalating use of mobilized peripheral blood cells as a preferred stem cell source, has led to a significant increase in the number of transplant survivors living with, and in some cases dying from, CGVHD [3-8]. Unfortunately, the treatment of established CGVHD remains unsatisfactory. Corticosteroids are the mainstay of therapy, but are often not fully effective, and their long-term use leads to multiple complications $[1,9]$. Other agents such as calcineurin inhibitors, sirolimus, mycophenolate mofetil, thalidomide, pentostatin, mesenchymal stem cells, and extracorporeal photopheresis have all produced responses in phase 2 studies, but no agent has yet demonstrated superiority to steroids alone in a randomized clinical trial [10-19].

During the past 3 decades, experimental studies and clinical observations have elucidated the pathophysiology of acute GVHD, but the biology of CGVHD has not been determined. In particular, defining the pathophysiology of CGVHD has been complicated by the absence of animal models that accurately recapitulate the disease or its clinical setting; this is in contrast to acute GVHD, in which murine models of

This is an Open Access article distributed under the terms of the Creative Commons Attribution Non-Commercial License (http://creativecommons.org/licenses/by-nc/3.0) which permits unrestricted non-commercial use, distribution, and reproduction in any medium, provided the original work is properly cited. 
major histocompatibility (MHC) mismatched HSCT provide a reasonably comprehensive picture of its pathophysiology as a clinical disease [20]. The purpose of this review is to briefly describe the pathophysiology of CGVHD, on the basis of phenotype and immunologic mechanisms that encompass the majority of murine CGVHD models described to date. Their relevance to clinical CGVHD is also discussed.

\section{DEFINITION}

CGVHD was initially defined as a GVHD syndrome that presents more than 100 days post-transplant, either as an extension of acute GVHD (progressive onset CGVHD), after a disease-free interval (quiescent CGVHD), or without preceding acute GVHD (de novo CGVHD) [21]. In patients with CGVHD, the skin can exhibit erythema with macules and plaques, desquamation, dyspigmentation, lichen planus, atrophy, and in severe cases, chronic ulcers. Chronic cholestatic liver disease can develop, as can involvement of the gastrointestinal tract, which may result in weight loss and malnutrition. CGVHD commonly produces sicca syndrome, which is caused by lymphocytic destruction of exocrine glands, most frequently affecting the eyes and mouth. The pathologic findings of CGVHD in the immune system include involution of thymic epithelium, lymphocyte depletion, and absence of secondary germinal centers in lymph nodes [22]. The skin pathology shows epidermal atrophy, dermal fibrosis, and sclerosis. Gastrointestinal lesions include inflammation and rarely, stenosis and stricture formation, particularly in the esophagus. Positive histological findings in the liver are often intensified versions of acute GVHD and include chronic changes, such as fibrosis, the hyalinization of portal triads, and bile duct obliteration. The glands of the skin and digestive tract show destruction of centrally draining ducts and secondary involvement of alveolar components. Pulmonary tissue can also be involved, although histological distinctions from bacterial and viral infections are sometimes difficult. Nevertheless, bronchiolitis obliterans, similar to that observed during lung transplant rejection, is now generally considered a manifestation of CGVHD.

\section{IMPORTANT CHANGES IN CLINICAL CONSIDERATIONS}

It is apparent that the clinical and histological changes considered characteristic of CGVHD can develop as early as 40 or 50 days post-transplant and thus, overlap with those of acute GVHD. Hence, the time of onset is increasingly becoming an arbitrary criterion, and it has become more meaningful to define the disease on the basis of clinical, histological, and immunologic findings.

The National Institutes of Health (NIH) have proposed new consensus criteria for the diagnosis and clinical assessment of CGVHD, which emphasize the manifestations of GVHD and not time of onset after allo-HSCT (day 100)
[23]. This proposal involves 2 categories for GVHD (acute or chronic), each with 2 subcategories (classic acute and late acute or classic chronic and overlap syndrome). In addition, a new scoring system is proposed to describe the extent and severity of CGVHD at each organ or site at any given time and that takes functional impact into account. The global composite scores produced and the numbers of organs or sites involved have been proposed as a means of assessing CGVHD severity, and it is expected that this system will replace the old grading system (limited versus extensive types). The feasibility of the NIH consensus criteria has been examined by us and others, and all studies have demonstrated the applicability of the new NIH criteria and described possible roles for the new global scoring system in the assessment of CGVHD severity [24-26].

\section{PATHOPHYSIOLOGY OF CGVHD}

Acute GVHD resembles a toxic, sepsis-like syndrome. Host antigen-presenting cells (APCs), especially dendritic cells (DCs), present alloantigens to incoming alloreactive cytotoxic $\mathrm{T}$ cells, and the subsequent actions of these $\mathrm{T}$ cells result in tissue damage to the epidermis, hepatic bile ducts, and gut epithelium. This process is amplified by cytokine release from damaged tissues and the ingress of lipopolysaccharide and other pathogen-associated molecular entities through damaged gut mucosa, which in turn up-regulate the innate immune system [27]. Not surprisingly, the immune mechanisms implicated in the induction and propagation of CGVHD differ from those of acute GVHD. However, the pathophysiology of CGVHD, unlike that of acute GVHD, remains obscure, as do its effective prevention and treatment. Fundamental research for the pathophysiology of CGVHD is required to develop more effective prophylactic and treatment regimens. So far, at least 4 theories have been generated to explain how CGVHD develops (Fig. 1).

\section{Breakage of immune tolerance to self-antigens (central tol- erance)}

It has been suggested that immune tolerance to self-antigens is disrupted in CGVHD, and that these give rise to the autoimmune manifestations of the disorder. One attractive hypothesis is that thymic epithelial damage caused by conditioning regimens and/or acute GVHD leads to dysregulation of central tolerance mechanisms during the reconstitution of the immune system post-transplantation [28]. $\mathrm{CD}^{+} \mathrm{T}$ cells generated de novo from donor stem cells appear to mediate the evolution of CGVHD from acute GVHD [29]. In fact, CGVHD occurs, even though it may not be preceded by acute GVHD. In healthy individuals, 95-99\% of double-positive $\mathrm{CD}^{+} \mathrm{CD}^{+}$immature $\mathrm{T}$ cells in the cortex of the thymus die through apoptosis, having failed to receive survival signals through their $\mathrm{T}$ cell receptors, a process referred to as "death by neglect." Those cells that do bind with low affinity to MHC class I or class II upregulate CD8 or CD4 respectively (positive selection) and survive. Since 


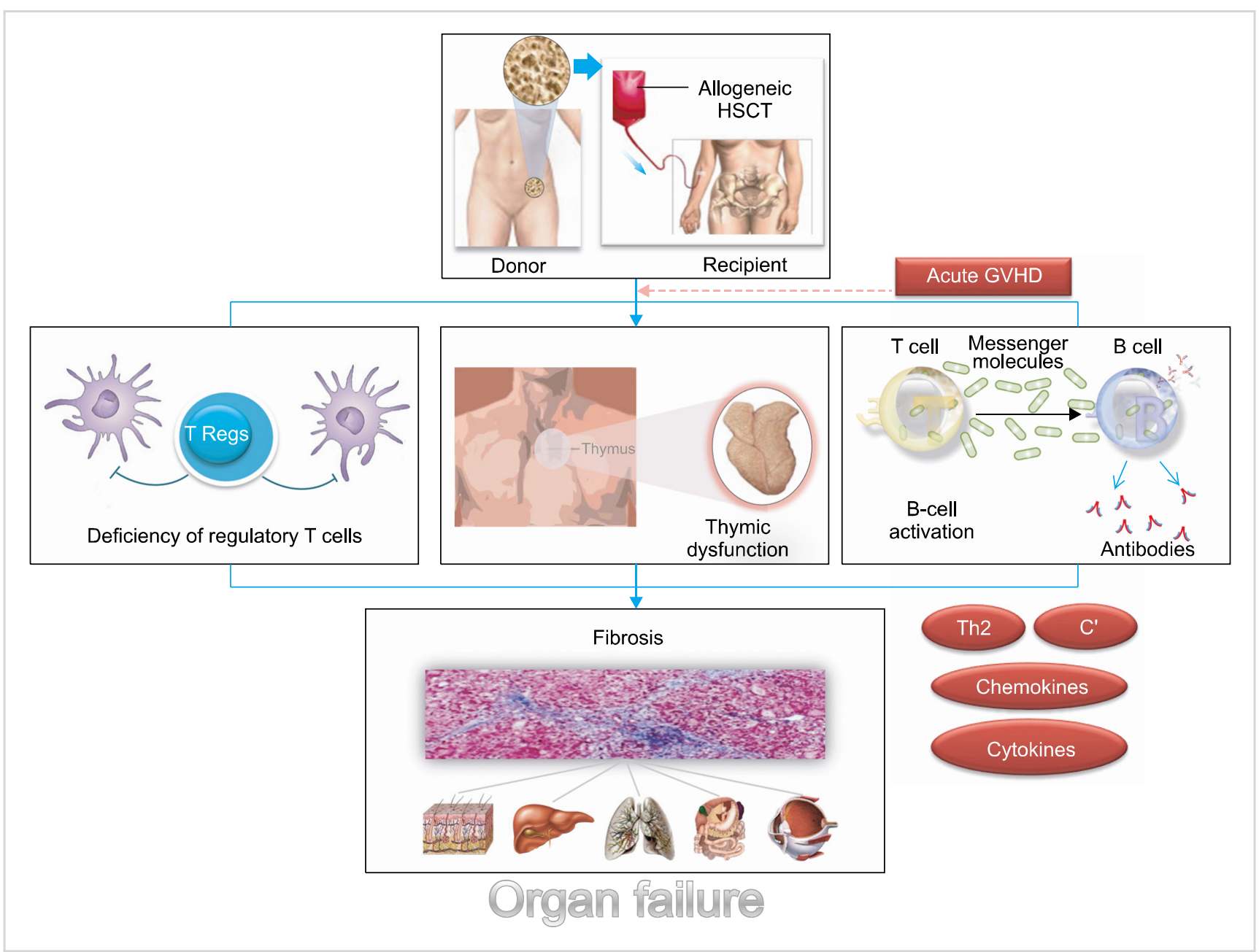

Fig. 1. The pathophysiology of chronic graft-versus-host disease.

self-antigens are also presented in the context of the cortical epithelial MHC complex, such $\mathrm{T}$ cells will have low self affinity. Furthermore, in the thymic medulla, single-positive $\mathrm{T}$ cells will encounter marrow-derived APCs also bearing self-antigens (sequestered from the blood) and if strongly autoreactive, will die by apoptosis (negative selection). Through these processes, low-affinity, self-reacting naïve $\mathrm{T}$ cells will enter the periphery, and when they encounter the same self-antigen/MHC complex, will receive survival but not activation signals. This balance between negative and positive selections may be lost in a pro-inflammatory environment and high tissue-specific autoantigen load. In this inflammatory environment, peripheral tolerance mechanisms would be critical for regulating GVHD.

In the setting of CGVHD, central tolerance failure could lead to an immune disease state resembling autoimmune disease. Although strategies based on the administration of keratinocyte growth factor at the time of transplant to prevent injury or repair thymic epithelium have been successful in experimental models [30], they failed in clinical trials [31]. Zhang found that host thymus is not required for the induction of CGVHD and that quiescent autoreactive $\mathrm{T}$ and
B cells in transplants from non-autoimmune donors might be activated and expanded to cause CGVHD [32]. In addition, Imado found that transfection of the hepatocyte growth factor (HGF) gene in vivo prevented the development of CGVHD in a murine model [33]. HGF also protected against thymic injury caused by acute GVHD and thus, prevented the generation of host-reactive $\mathrm{T}$ cells and the development of CGVHD.

2. $\mathrm{CD}^{+} \mathrm{CD}^{+} 5^{+}$regulatory $\mathrm{T}$ cells (Tregs) and their relationship to CGVHD

In several series, regulatory $\mathrm{T}$ cell (Treg) numbers (determined by $\mathrm{CD}^{+} \mathrm{CD} 25^{+} \mathrm{FoxP}^{+}$staining) have been reported to be diminished in CGVHD [34-36], although data reported on Treg numbers and the occurrence of CGVHD are contradictory. Clark found that CGVHD is associated with elevated numbers of peripheral blood Tregs and that these numbers returned to normal in patients with resolved CGVHD, thus indicating that CGVHD injury is not the result of Treg deficiency [37]. The mechanism by which Tregs suppress CGVHD remains uncertain, but there is evidence that suppression is mediated by cytokines, such as transforming 
growth factor (TGF)- $\beta$ and interleukin (IL)-10, or by contact with plasmacytoid DCs through indoleamine 2,3-dioxygenase [38]. Tregs may also exert an inhibitory influence directly in target tissues [39]. For example, mucosal Treg numbers have been documented to be lower in patients with GVHD than in normal controls or patients without GVHD [34]. Interestingly, extracorporeal photochemotherapy increases levels of circulating functional Tregs in CGVHD patients [40], and recently, a novel photodepleting approach was found to both preserve and expand Treg numbers while selectively eliminating $\mathrm{CD}^{+}$effector $\mathrm{T}$ cells from patients with CGVHD [41].

The adoptive transfer of Tregs in animal models of GVHD has demonstrated their efficacy, which suggests that Tregs can be exploited in the clinical setting [42]. Giorgini concluded that alloantigen-driven expansion, rather than homeostatic proliferation, is critical for the effectiveness of Tregs in CGVHD, and suggested that cellular therapy with alloantigen-induced Tregs in combination with glucocorticoids could prevent CGVHD after immune reconstitution [43]. Zhang, using a murine study, suggested that peripheral tolerance may be more critical and abrogated by donor Tregs [32], and Chen associated the absence of Treg control of $\mathrm{T}$ helper (Th) 1 and Th17 cells with an autoimmune-mediated pathology in CGVHD [44].

\section{The roles of B cells and the antibodies they produce}

Historically, research into the prevention and treatment of GVHD centered on donor T lymphocytes and strategies designed to suppress or deplete these cells. The roles of B lymphocytes in the pathogenesis of GVHD were highlighted by a case report of a patient with CGVHD who responded to $\mathrm{B}$ cell depletion therapy based on rituximab [45]. Considerable laboratory evidence has since revealed complex interactions between $\mathrm{B}$ and $\mathrm{T}$ cells that culminate in CGVHD. There are numerous examples of autoantibody formation in patients with CGVHD, but the role of autoantibody formation in its pathogenesis has not been elucidated [46]. One study, in which antibodies to platelet-derived growth factor (PDGF) were observed in patients with CGVHD but not in those without CGVHD, was of particular note [47]. These antibodies were found to have the capacity to induce both tyrosine phosphorylation of the PDGF receptor and type I collagen gene expression in fibroblasts. The role of $\mathrm{B}$ cell activity in CGVHD is underscored by the observation of high plasma levels of B cell activating factor (BAFF), a cytokine that appears to drive B cell autoimmunity, in patients with CGVHD [48]. In fact, high plasma levels of BAFF at 6 months post-transplantation were found to predict the subsequent development of CGVHD in asymptomatic patients. The development of antibodies to minor histocompatibility antigens ( $\mathrm{mHA}$ ) encoded on the Y chromosome in male patients receiving female grafts has been strongly associated with CGVHD incidence [49]. Since this was originally observed [45], several clinical trials and case series have been conducted on the use of $\mathrm{B}$ cell depletion using rituximab to treat CGVHD. The evidence obtained supports the roles of B cells and antibodies in CGVHD and prompted trials of rituximab. In phase 2 trials, responses were documented in over $50 \%$ of subjects [50]. Recently, Korean researchers performed a definitive trial in an attempt to establish the efficacy of rituximab and concluded that $\mathrm{B}$ cells represent a promising target for the prevention and treatment of CGVHD [51]. Although studies on B cell depletion in CGVHD have demonstrated the clinical effectiveness of this strategy, the mechanisms underlying the exact role of B cells on CGVHD are not entirely clear. In a murine study on the topic, it was suggested that donor B cell depletion protected mice from CGVHD [32], and therefore, it is conceivable that alloreactive donor $\mathrm{CD}^{+} \mathrm{T}$ cells could be activated by host $\mathrm{B}$ cells, and that this, in turn, promotes the activation and expansion of quiescent autoreactive donor B cells in stem cell grafts. Furthermore, these autoreactive B cells could have a central role in amplification of autoimmune responses and in the epitope spreading of autoreactive $\mathrm{T}$ and $\mathrm{B}$ cells [52]. Another model of lupus CGVHD showed that the cytotoxic $\mathrm{T}$ lymphocyte (CTL)- promoting properties of CD40 stimulation outweigh $\mathrm{CD}^{+} \mathrm{T}$ cell-driven B cell hyperactivity [53].

\section{Fibrotic changes}

In the skin, the initial phase of CGVHD is characterized by an intense mononuclear inflammatory infiltrate and destructive changes at the dermal-epidermal junction, accompanied by irregular acanthosis, hyperkeratosis, atrophy, progressing to dermal fibrosis and sclerosis [54]. Other hallmarks of CGVHD include the destruction of tubuloalveolar glands, ducts in the skin, salivary and lacrimal glands, respiratory epithelium, and bile ducts. A large number of experimental models have indicated an association between type 2 polarized immune responses and the development of fibrosis [55]. In particular, donor type 2 immune responses were found to be required for the induction of cutaneous GVHD in mice [56]. Furthermore, Hillebrandt found that complement factor 5 (C5) dose-dependently modified liver fibrosis in mice and humans [57]. C5b-9 complexes are deposited in the skin, liver, lung, and kidney in mice with GVHD [58]. C3 is deposited at the dermal-epidermal junction in humans with CGVHD [59], but deposition of C5b-9 complexes has not been described in man. One study found that serum levels of TGF- $\beta$ were higher in patients with CGVHD than in patients without CGVHD [60]. The interpretation of this result is complicated because assays were carried out with serum and not plasma, and serum contains large amounts of TGF- $\beta$ released by platelets during clotting. Gene expression studies have demonstrated that increased TGF- $\beta$ signaling in CD4 cells and CD8 cells is associated with a reduced risk of CGVHD in man [61]. The association between increased TGF- $\beta$ activity and a reduced risk of CGVHD might result from a lower risk of acute GVHD, since acute GVHD is a well-recognized risk factor of CGVHD. Furthermore, skin fibrosis and the upregulation of TGF- $\beta 1$ and collagen mRNAs commonly occur in human scleroderma and murine sclerodermatous GVHD following transplantation of B10.D2 
lymphoid cells into irradiated BALB/c recipients [62].

There is now considerable evidence that the preferential expansion of Th2 cells after allo-HSCT is associated with the development of CGVHD in both murine models and humans [63-68]. As is shown by most experimental models of fibrosis, $\mathrm{CD}^{+} \mathrm{T}$ cells play an important role in the progression of CGVHD, and the type of $\mathrm{CD}^{+} \mathrm{T}$-cell response that develops is crucial. Studies using various cytokine-deficient mice have shown that fibrogenesis is strongly linked with the development of a Th2 $\mathrm{CD} 4{ }^{+} \mathrm{T}$-cell response and that this involves IL-4, IL-5, and IL-13 [69]. Although an equally potent inflammatory response develops when Th1 $\mathrm{CD}^{+} \mathrm{T}$ cells, which produce interferon (IFN) $-\gamma$, dominate [70], under these circumstances, the development of tissue fibrosis is almost completely attenuated. These studies show that chronic inflammation does not always induce the deposition of connective-tissue elements and that the magnitude of fibrosis is tightly regulated by the phenotype of the developing Th-cell response. Furthermore, IL-13 and IL-4 bind to the same signaling receptor (IL-4R $\alpha$-IL-13R $\alpha 1$ ) on fibroblasts [71]. Indeed, studies carried out using several fibroblast subtypes have demonstrated the potent collagen-inducing activities of IL-4 and IL-13 [72-74]. In addition, when the productions of IL-4 and IL-13 from fibroblasts are compared, the concentration of IL-13 often exceeds that of IL- 4 by a factor of 10-100. This suggests that IL-13 uses a signaling pathway that is different in some way from that used by IL-4, which could provide a means of augmenting its fibrogenic potential. In contrast to IL-13, the extent to which IL-5 and eosinophils participate in fibrotic processes varies greatly, and no clear explanation has been proposed that adequately explains the widely divergent findings. However, Jacobsohn found that monitoring the peripheral eosinophil count post-transplantation might provide a means of detecting the development of CGVHD [75].

Chemokines are potent leukocyte chemoattractants that cooperate with pro-fibrotic cytokines such as IL-13 and TGF- $\beta$ during the development of fibrosis by recruiting macrophages and other effector cells to sites of tissue damage. Chemokines and their receptors have been implicated in the pathogenesis of scleroderma by recruiting immune cells to target tissues and thus, contribute to tissue damage [76]. Although numerous chemokine signaling pathways are probably involved in fibrogenesis, the CC-chemokine family has been shown to play an important regulatory role. In particular, CCL3 (macrophage inflammatory protein $1 \alpha$, MIP-1 $\alpha$ ) and CCL2 (monocyte chemoattractant protein 1, MCP-1) are chemotactic for mononuclear phagocytes and have been identified to be essential pro-fibrotic mediators. In a murine CGVHD model, high levels of chemokine mRNAs, i.e., MCP-1, CCL5 (RANTES), CCL17, and IFN- $\gamma$-inducible chemokines (CXCL9/Mig, CXCL10/IP-10, and CXCL11/I-TAC), which are all monocyte/macrophage- and $\mathrm{T}$ cell-related, were observed from days 7 to 120 post-transplantation [77]. In a previous study, we found that pravastatin attenuates murine CGVHD by blocking the influx of effector cells into target organs and by downregulating the protein expressions of MCP-1 and RANTES, thereby reducing collagen synthesis [78].

\section{CGVHD ANIMAL MODELS}

Several murine allo-HSCT models have been used to study the pathogenesis of CGVHD. The first type of model involves the transplantation of parental lymphocytes into non-irradiated MHC-mismatched F1 recipients [79, 80]. In this model type, F1 recipients develop high levels of serum anti-doublestrand DNA (dsDNA) and glomerulonephritis, and autoantibody production is the result of a cognate interaction between donor $\mathrm{CD}^{+} \mathrm{T}$ cells and host B cells [79, 81-83]. However, it is not clear whether mechanisms revealed by this model reflect the pathogenesis of CGVHD in human transplant recipients receiving conditioning.

The second type of model involves the transplantation of donor lymphocytes into MHC-matched but mHA-mismatched irradiated recipients. In this model, donor LP/J $\left(\mathrm{H}-2^{\mathrm{b}}\right)$ bone marrow and spleen cells were transplanted into lethally irradiated $\mathrm{C} 57 \mathrm{BL} / 6\left(\mathrm{H}-2^{\mathrm{b}}\right)$ recipients, which later developed acute and chronic forms of GVHD [84]. Clonal analysis of $\mathrm{T}$ cells from the $\mathrm{C} 57 \mathrm{BL} / 6$ recipients indicated that acute GVHD development was due primarily to recipient-specific donor CTL, whereas CGVHD development was caused by autoreactive $\mathrm{CD} 4^{+} \mathrm{T}$ lymphocytes [84].

In another mHA-disparate model, B10D2 $\left(\mathrm{H}-2^{\mathrm{d}}\right)$ donor spleen cells were transplanted into lethally irradiated BALB/c recipients, which then developed sclerodermatous organ damage [32, 85]. Skin changes in this model include a mononuclear infiltrate deep in dermis, loss of dermal fat, increased collagen deposition, and "dropout" of dermal appendages, such as hair follicles; unlike that found in acute GVHD, the apoptosis of basal epithelial cells at the dermal-epidermal junction does not occur. Clinical manifestations begin as early as day 11 post-transplantation, and cutaneous fibrosis is apparent as early as day 21. Deposits of $\operatorname{IgG}, \operatorname{IgA}$, and IgM appear at the dermal epidermal junction in recipients [85]. Additional features of CGVHD in this model include inflammation and fibrosis in salivary and lacrimal glands, sclerosing cholangitis, progressive renal and gastrointestinal fibrosis, and the development of anti-Scl-70 antibody [86]. Naïve donor CD4 cells initiate the disease in this strain combination [87], and the dermal infiltrate is comprised of $\mathrm{T}$ cells, monocytes, and macrophages [88]. $\mathrm{T}$ cells and macrophages in skin express TGF- $\beta 1$ but not TGF- $\beta 2$ or TGF- $\beta 3$ mRNA [89]. In a microarray analysis study, the expression of type 1 (IFN- $\gamma$ ) and type 2 (IL-6, IL-10, and IL-13) cytokines, chemokines, and a variety of growth factors and cell adhesion molecules were upregulated in recipients with CGVHD compared to recipients without it [77].

Zhang developed a new type of CGVHD model based on the transplantation of DBA/2 $\left(\mathrm{H}-2^{\mathrm{d}}\right)$ spleen cells into MHC-matched but mHA-mismatched, sub-lethally irradiated $\mathrm{BALB} / \mathrm{c}\left(\mathrm{H}-2^{\mathrm{d}}\right)$ recipients; in this model, both donor $\mathrm{CD} 25^{-} \mathrm{CD} 4^{+} \mathrm{T}$ cells and $\mathrm{B}$ cells were required for CGVHD 
development [32]. However, the relevance of this model for human CGVHD is questionable because even though dsDNA-specific autoantibodies, immune complex glomerulonephritis, and proteinuria are characteristic of systemic lupus, they rarely occur in patients with CGVHD [90].

\section{CONCLUSION}

Alloreactivity forms the basis of the pathogenesis of CGVHD, but the phenotypes and origins of the alloreactive cells involved remain somewhat ambiguous. Attempts to study CGVHD experimentally have been somewhat hampered by the absence of a reliable animal model that exactly represents variable manifestations in humans. Nevertheless, thymic dysfunction, Treg deficiency, autoantibody formation with B cell activation, and dysregulatory fibrotic processes have been shown to be associated with the occurrence of CGVHD. Fundamental research on the pathophysiology of CGVHD is required for the development of more effective prophylactic and treatment regimens. Finally, improved methods of diagnosis and staging based on an understanding of the pathogenesis of CGVHD should help to exploit novel therapeutic approaches in the future.

\section{REFERENCES}

1. Lee SJ, Vogelsang G, Flowers ME. Chronic graft-versus-host disease. Biol Blood Marrow Transplant 2003;9:215-33.

2. Baird K, Pavletic SZ. Chronic graft versus host disease. Curr Opin Hematol 2006;13:426-35.

3. Lee SJ, Klein JP, Barrett AJ, et al. Severity of chronic graft-versus-host disease: association with treatment-related mortality and relapse. Blood 2002;100:406-14.

4. Socié G, Stone JV, Wingard JR, et al. Long-term survival and late deaths after allogeneic bone marrow transplantation. Late Effects Working Committee of the International Bone Marrow Transplant Registry. N Engl J Med 1999;341:14-21.

5. Lee SJ, Kim HT, Ho VT, et al. Quality of life associated with acute and chronic graft-versus-host disease. Bone Marrow Transplant 2006;38:305-10.

6. Fraser CJ, Bhatia S, Ness K, et al. Impact of chronic graft-versus-host disease on the health status of hematopoietic cell transplantation survivors: a report from the Bone Marrow Transplant Survivor Study. Blood 2006;108:2867-73.

7. Cutler C, Giri S, Jeyapalan S, Paniagua D, Viswanathan A, Antin $\mathrm{JH}$. Acute and chronic graft-versus-host disease after allogeneic peripheral-blood stem-cell and bone marrow transplantation: a meta-analysis. J Clin Oncol 2001;19:3685-91.

8. Schmitz N, Eapen M, Horowitz MM, et al. Long-term outcome of patients given transplants of mobilized blood or bone marrow: a report from the International Bone Marrow Transplant Registry and the European Group for Blood and Marrow Transplantation. Blood 2006;108:4288-90.

9. Akpek G, Lee SM, Anders V, Vogelsang GB. A high-dose pulse steroid regimen for controlling active chronic graft-versus-host disease. Biol Blood Marrow Transplant 2001;7:495-502.

10. Arora M, Wagner JE, Davies SM, et al. Randomized clinical trial of thalidomide, cyclosporine, and prednisone versus cyclosporine and prednisone as initial therapy for chronic graft-versus-host disease. Biol Blood Marrow Transplant 2001;7:265-73.

11. Lopez F, Parker P, Nademanee A, et al. Efficacy of mycophenolate mofetil in the treatment of chronic graft-versus-host disease. Biol Blood Marrow Transplant 2005;11:307-13.

12. Busca A, Locatelli F, Marmont F, Audisio E, Falda M. Response to mycophenolate mofetil therapy in refractory chronic graft-versus-host disease. Haematologica 2003;88:837-9.

13. Goldberg JD, Jacobsohn DA, Margolis J, et al. Pentostatin for the treatment of chronic graft-versus-host disease in children. J Pediatr Hematol Oncol 2003;25:584-8.

14. Carnevale-Schianca F, Martin P, Sullivan K, et al. Changing from cyclosporine to tacrolimus as salvage therapy for chronic graftversus-host disease. Biol Blood Marrow Transplant 2000;6:61320.

15. Couriel DR, Hosing C, Saliba R, et al. Extracorporeal photochemotherapy for the treatment of steroid-resistant chronic GVHD. Blood 2006;107:3074-80.

16. Couriel DR, Saliba R, Escalón MP, et al. Sirolimus in combination with tacrolimus and corticosteroids for the treatment of resistant chronic graft-versus-host disease. Br J Haematol 2005;130:40917.

17. Foss FM, DiVenuti GM, Chin K, et al. Prospective study of extracorporeal photopheresis in steroid-refractory or steroid-resistant extensive chronic graft-versus-host disease: analysis of response and survival incorporating prognostic factors. Bone Marrow Transplant 2005;35:1187-93.

18. Greinix HT, Volc-Platzer B, Rabitsch W, et al. Successful use of extracorporeal photochemotherapy in the treatment of severe acute and chronic graft-versus-host disease. Blood 1998;92:3098104.

19. Johnston LJ, Brown J, Shizuru JA, et al. Rapamycin (sirolimus) for treatment of chronic graft-versus-host disease. Biol Blood Marrow Transplant 2005;11:47-55.

20. Ferrara JL, Levy R, Chao NJ. Pathophysiologic mechanisms of acute graft-vs.-host disease. Biol Blood Marrow Transplant 1999;5:347-56.

21. Sullivan KM, Shulman HM, Storb R, et al. Chronic graft-versus-host disease in 52 patients: adverse natural course and successful treatment with combination immunosuppression. Blood 1981;57:267-76.

22. Imanguli MM, Alevizos I, Brown R, Pavletic SZ, Atkinson JC. Oral graft-versus-host disease. Oral Dis 2008;14:396-412.

23. Filipovich AH, Weisdorf D, Pavletic S, et al. National Institutes of Health consensus development project on criteria for clinical trials in chronic graft-versus-host disease: I. Diagnosis and staging working group report. Biol Blood Marrow Transplant 2005;11: 945-56.

24. Arora M, Nagaraj S, Witte J, et al. New classification of chronic GVHD: added clarity from the consensus diagnoses. Bone Marrow Transplant 2009;43:149-53.

25. Cho BS, Min CK, Eom KS, et al. Feasibility of NIH consensus criteria for chronic graft-versus-host disease. Leukemia 2009;23: 78-84. 
26. Vigorito AC, Campregher PV, Storer BE, et al. Evaluation of $\mathrm{NIH}$ consensus criteria for classification of late acute and chronic GVHD. Blood 2009;114:702-8.

27. Choi SW, Levine JE, Ferrara JL. Pathogenesis and management of graft-versus-host disease. Immunol Allergy Clin North Am 2010; 30:75-101.

28. Sprent J, Kishimoto $H$. The thymus and central tolerance. Transplantation 2001;72(Suppl 8):S25-8.

29. Dutt S, Tseng D, Ermann J, et al. Naive and memory T cells induce different types of graft-versus-host disease. J Immunol 2007;179: 6547-54.

30. Panoskaltsis-Mortari A, Lacey DL, Vallera DA, Blazar BR. Keratinocyte growth factor administered before conditioning ameliorates graft-versus-host disease after allogeneic bone marrow transplantation in mice. Blood 1998;92:3960-7.

31. Blazar BR, Weisdorf DJ, Defor T, et al. Phase 1/2 randomized, placebo-control trial of palifermin to prevent graft-versus-host disease (GVHD) after allogeneic hematopoietic stem cell transplantation (HSCT). Blood 2006;108:3216-22.

32. Zhang C, Todorov I, Zhang Z, et al. Donor CD4+ T and B cells in transplants induce chronic graft-versus-host disease with autoimmune manifestations. Blood 2006;107:2993-3001.

33. Imado T, Iwasaki T, Kataoka Y, et al. Hepatocyte growth factor preserves graft-versus-leukemia effect and T-cell reconstitution after marrow transplantation. Blood 2004;104:1542-9.

34. Rieger K, Loddenkemper C, Maul J, et al. Mucosal FOXP3+ regulatory $\mathrm{T}$ cells are numerically deficient in acute and chronic GvHD. Blood 2006;107:1717-23.

35. Anderson BE, McNiff JM, Matte C, Athanasiadis I, Shlomchik WD, Shlomchik MJ. Recipient CD4+ T cells that survive irradiation regulate chronic graft-versus-host disease. Blood 2004;104: 1565-73.

36. Zorn E, Kim HT, Lee SJ, et al. Reduced frequency of FOXP3+ CD4+CD25+ regulatory T cells in patients with chronic graft-versus-host disease. Blood 2005;106:2903-11.

37. Clark FJ, Gregg R, Piper K, et al. Chronic graft-versus-host disease is associated with increased numbers of peripheral blood CD4+CD25high regulatory T cells. Blood 2004;103:2410-6.

38. Sharma MD, Baban B, Chandler P, et al. Plasmacytoid dendritic cells from mouse tumor-draining lymph nodes directly activate mature Tregs via indoleamine 2,3-dioxygenase. J Clin Invest 2007;117:2570-82.

39. Nguyen VH, Zeiser R, Dasilva DL, et al. In vivo dynamics of regulatory T-cell trafficking and survival predict effective strategies to control graft-versus-host disease following allogeneic transplantation. Blood 2007;109:2649-56.

40. Di Biaso I, Di Maio L, Bugarin C, et al. Regulatory T cells and extracorporeal photochemotherapy: correlation with clinical response and decreased frequency of proinflammatory $\mathrm{T}$ cells. Transplantation 2009;87:1422-5.

41. Bastien JP, Krosl G, Therien C, et al. Photodepletion differentially affects CD4+ Tregs versus CD4+ effector T cells from patients with chronic graft-versus-host disease. Blood 2010;116:4859-69.

42. Hoffmann P, Ermann J, Edinger M, Fathman CG, Strober S. Donor-type CD4(+)CD25(+) regulatory T cells suppress lethal acute graft-versus-host disease after allogeneic bone marrow transplantation. J Exp Med 2002;196:389-99.
43. Giorgini A, Noble A. Blockade of chronic graft-versus-host disease by alloantigen-induced CD4+CD25+Foxp3+ regulatory $\mathrm{T}$ cells in nonlymphopenic hosts. J Leukoc Biol 2007;82:1053-61.

44. Chen X, Vodanovic-Jankovic S, Johnson B, Keller M, Komorowski R, Drobyski WR. Absence of regulatory T-cell control of TH1 and TH17 cells is responsible for the autoimmune-mediated pathology in chronic graft-versus-host disease. Blood 2007;110:3804-13.

45. Ratanatharathorn V, Carson E, Reynolds C, et al. Anti-CD20 chimeric monoclonal antibody treatment of refractory immunemediated thrombocytopenia in a patient with chronic graft-versus-host disease. Ann Intern Med 2000;133:275-9.

46. Patriarca F, Skert C, Sperotto A, et al. The development of autoantibodies after allogeneic stem cell transplantation is related with chronic graft-vs-host disease and immune recovery. Exp Hematol 2006;34:389-96.

47. Svegliati S, Olivieri A, Campelli N, et al. Stimulatory autoantibodies to PDGF receptor in patients with extensive chronic graft-versus-host disease. Blood 2007;110:237-41.

48. Sarantopoulos S, Stevenson KE, Kim HT, et al. High levels of B-cell activating factor in patients with active chronic graft-versus-host disease. Clin Cancer Res 2007;13:6107-14.

49. Miklos DB, Kim HT, Miller KH, et al. Antibody responses to H-Y minor histocompatibility antigens correlate with chronic graftversus-host disease and disease remission. Blood 2005;105:29738.

50. Cutler C, Miklos D, Kim HT, et al. Rituximab for steroid-refractory chronic graft-versus-host disease. Blood 2006;108:756-62.

51. Kim SJ, Lee JW, Jung CW, et al. Weekly rituximab followed by monthly rituximab treatment for steroid-refractory chronic graft-versus-host disease: results from a prospective, multicenter, phase II study. Haematologica 2010;95:1935-42.

52. Alousi AM, Uberti J, Ratanatharathorn V. The role of B cell depleting therapy in graft versus host disease after allogeneic hematopoietic cell transplant. Leuk Lymphoma 2010;51:376-89.

53. Puliaev R, Puliaeva I, Welniak LA, et al. CTL-promoting effects of CD40 stimulation outweigh B cell-stimulatory effects resulting in B cell elimination and disease improvement in a murine model of lupus. J Immunol 2008;181:47-61.

54. Shulman HM, Kleiner D, Lee SJ, et al. Histopathologic diagnosis of chronic graft-versus-host disease: National Institutes of Health Consensus Development Project on Criteria for Clinical Trials in Chronic Graft-versus-Host Disease: II. Pathology Working Group Report. Biol Blood Marrow Transplant 2006;12:31-47.

55. Wynn TA. Fibrotic disease and the $\mathrm{T}(\mathrm{H}) 1 / \mathrm{T}(\mathrm{H}) 2$ paradigm. Nat Rev Immunol 2004;4:583-94.

56. Nikolic B, Lee S, Bronson RT, Grusby MJ, Sykes M. Th1 and Th2 mediate acute graft-versus-host disease, each with distinct end-organ targets. J Clin Invest 2000;105:1289-98.

57. Hillebrandt $\mathrm{S}$, Wasmuth HE, Weiskirchen R, et al. Complement factor 5 is a quantitative trait gene that modifies liver fibrogenesis in mice and humans. Nat Genet 2005;37:835-43.

58. Niculescu F, Niculescu T, Nguyen P, et al. Both apoptosis and complement membrane attack complex deposition are major features of murine acute graft-vs.-host disease. Exp Mol Pathol 2005;79: $136-45$.

59. Tsoi MS, Storb R, Jones E, et al. Deposition of IgM and complement at the dermoepidermal junction in acute and chronic cutaneous 
graft-vs-host disease in man. J Immunol 1978;120:1485-92.

60. Liem LM, Fibbe WE, van Houwelingen HC, Goulmy E. Serum transforming growth factor-beta1 levels in bone marrow transplant recipients correlate with blood cell counts and chronic graft-versus-host disease. Transplantation 1999;67:59-65.

61. Baron C, Somogyi R, Greller LD, et al. Prediction of graft-versushost disease in humans by donor gene-expression profiling. PLoS Med 2007;4:e23.

62. Jaffee BD, Claman HN. Chronic graft-versus-host disease (GVHD) as a model for scleroderma. I. Description of model systems. Cell Immunol 1983;77:1-12.

63. Allen RD, Staley TA, Sidman CL. Differential cytokine expression in acute and chronic murine graft-versus-host-disease. Eur J Immunol 1993;23:333-7.

64. De Wit D, Van Mechelen M, Zanin C, et al. Preferential activation of Th2 cells in chronic graft-versus-host reaction. J Immunol 1993;150:361-6.

65. Doutrelepont JM, Moser M, Leo O, et al. Hyper IgE in stimulatory graft-versus-host disease: role of interleukin-4. Clin Exp Immunol 1991;83:133-6.

66. Garlisi CG, Pennline KJ, Smith SR, Siegel MI, Umland SP. Cytokine gene expression in mice undergoing chronic graft-versus-host disease. Mol Immunol 1993;30:669-77.

67. Tanaka J, Imamura M, Kasai M, et al. The important balance between cytokines derived from type 1 and type 2 helper $\mathrm{T}$ cells in the control of graft-versus-host disease. Bone Marrow Transplant 1997;19:571-6.

68. Umland SP, Razac S, Nahrebne DK, Seymour BW. Effects of in vivo administration of interferon (IFN)-gamma, anti-IFN-gamma, or anti-interleukin-4 monoclonal antibodies in chronic autoimmune graft-versus-host disease. Clin Immunol Immunopathol 1992;63:66-73.

69. Wynn TA, Cheever AW, Jankovic D, et al. An IL-12-based vaccination method for preventing fibrosis induced by schistosome infection. Nature 1995;376:594-6.

70. Hoffmann KF, Cheever AW, Wynn TA. IL-10 and the dangers of immune polarization: excessive type 1 and type 2 cytokine responses induce distinct forms of lethal immunopathology in murine schistosomiasis. J Immunol 2000;164:6406-16.

71. Murata T, Husain SR, Mohri H, Puri RK. Two different IL-13 receptor chains are expressed in normal human skin fibroblasts, and IL-4 and IL-13 mediate signal transduction through a common pathway. Int Immunol 1998;10:1103-10.

72. Chiaramonte MG, Donaldson DD, Cheever AW, Wynn TA. An IL-13 inhibitor blocks the development of hepatic fibrosis during a T-helper type 2-dominated inflammatory response. J Clin Invest 1999;104:777-85.

73. Oriente A, Fedarko NS, Pacocha SE, Huang SK, Lichtenstein LM, Essayan DM. Interleukin-13 modulates collagen homeostasis in human skin and keloid fibroblasts. J Pharmacol Exp Ther 2000; 292:988-94.

74. Saito A, Okazaki H, Sugawara I, Yamamoto K, Takizawa H. Potential action of IL-4 and IL-13 as fibrogenic factors on lung fibroblasts in vitro. Int Arch Allergy Immunol 2003;132:168-76.

75. Jacobsohn DA, Schechter T, Seshadri R, Thormann K, Duerst R,
Kletzel M. Eosinophilia correlates with the presence or development of chronic graft-versus-host disease in children. Transplantation 2004;77:1096-100.

76. Atamas SP, White B. The role of chemokines in the pathogenesis of scleroderma. Curr Opin Rheumatol 2003;15:772-7.

77. Zhou L, Askew D, Wu C, Gilliam AC. Cutaneous gene expression by DNA microarray in murine sclerodermatous graft-versus-host disease, a model for human scleroderma. J Invest Dermatol 2007;127:281-92.

78. Yoon HK, Lim JY, Kim TJ, Cho CS, Min CK. Effects of pravastatin on murine chronic graft-versus-host disease. Transplantation 2010;90:853-60.

79. Morris SC, Cheek RL, Cohen PL, Eisenberg RA. Allotype-specific immunoregulation of autoantibody production by host $\mathrm{B}$ cells in chronic graft-versus host disease. J Immunol 1990;144:916-22.

80. van der Veen FM, Rolink AG, Gleichmann E. Autoimmune disease strongly resembling systemic lupus erythematosus (SLE) in F1 mice undergoing graft-versus-host reaction (GVHR). Adv Exp Med Biol 1982;149:669-77.

81. Sekiguchi DR, Eisenberg RA, Weigert M. Secondary heavy chain rearrangement: a mechanism for generating anti-double-stranded DNA B cells. J Exp Med 2003;197:27-39.

82. Sekiguchi DR, Jainandunsing SM, Fields ML, et al. Chronic graft-versus-host in Ig knockin transgenic mice abrogates B cell tolerance in anti-double-stranded DNA B cells. J Immunol 2002; 168:4142-53.

83. Via CS, Shearer GM. T-cell interactions in autoimmunity: insights from a murine model of graft-versus-host disease. Immunol Today 1988;9:207-13.

84. Parkman R. Clonal analysis of murine graft-vs-host disease. I. Phenotypic and functional analysis of $\mathrm{T}$ lymphocyte clones. J Immunol 1986;136:3543-8.

85. Claman HN, Jaffee BD, Huff JC, Clark RA. Chronic graft-versus-host disease as a model for scleroderma. II. Mast cell depletion with deposition of immunoglobulins in the skin and fibrosis. Cell Immunol 1985;94:73-84.

86. Ruzek MC, Jha S, Ledbetter S, Richards SM, Garman RD. A modified model of graft-versus-host-induced systemic sclerosis (scleroderma) exhibits all major aspects of the human disease. Arthritis Rheum 2004;50:1319-31.

87. Anderson BE, McNiff J, Yan J, et al. Memory CD4+ T cells do not induce graft-versus-host disease. J Clin Invest 2003;112:101-8.

88. McCormick LL, Zhang Y, Tootell E, Gilliam AC. Anti-TGF-beta treatment prevents skin and lung fibrosis in murine sclerodermatous graft-versus-host disease: a model for human scleroderma. J Immunol 1999;163:5693-9.

89. Zhang Y, McCormick LL, Desai SR, Wu C, Gilliam AC. Murine sclerodermatous graft-versus-host disease, a model for human scleroderma: cutaneous cytokines, chemokines, and immune cell activation. J Immunol 2002;168:3088-98.

90. Rouquette-Gally AM, Boyeldieu D, Prost AC, Gluckman E. Autoimmunity after allogeneic bone marrow transplantation. A study of 53 long-term-surviving patients. Transplantation 1988; 46:238-40. 